\author{
Asian Journal of \\ Medical and Biological Research \\ ISSN 2411-4472 \\ www.ebupress.com/journal/ajmbr
}

\title{
Article
}

\section{Seasonal variation of water quality parameters, clinical and histological observation of some small endangered open water fishes from Mymensingh and Sylhet region}

\author{
Md. Mamunur Rahman*, Gias Uddin Ahmed and Md. Tawhid Hasan \\ Department of Aquaculture, Faculty of Fisheries, Bangladesh Agricultural University, Mymensingh-2202, \\ Bangladesh \\ *Corresponding author: Md. Mamunur Rahman, Department of Aquaculture, Faculty of Fisheries, Bangladesh \\ Agricultural University, Mymensingh-2202, Bangladesh. Email: mamunurrahman125@gmail.com
}

Received: 19 May 2015/Accepted: 18 June 2015/ Published: 30 June 2015

\begin{abstract}
Seasonal variation of water quality parameters and health condition of some small endangered open water fishes are Baila (Glossogobius giuris), Gutum (Lepidocephalichthys guntea) and Tara baim (Macrognathus aculeatus) was carried out through clinical and histological observation from Kailla beel of Ishargonj upazila, Mymensingh and Surma river, Gobindogonj upazila, Sunamgonj district, Sylhet region for a period of eight months from September 2014 to April 2015. Water quality parameters like water temperature, dissolved oxygen, $\mathrm{pH}$, ammonia, alkalinity, hardness, and nitrate were recorded. Water temperature, $\mathrm{pH}$, alkalinity and hardness were found at unfavorable level for fish in mid November and January. Clinical examinations of the fish were carried out at monthly intervals and any kind of abnormalities were recorded. Clinically it was observed that, fish was affected with fin and tail rot, gill rot, parasitic infestation, nutritional deformities, numerous red spots and patches in lateral and ventral regions, large deep whitish ulcers reached up to deep ulcers especially in December and January in both region. Samples of skin, muscle, gill, liver and kidney were collected and processed for histological observations. Major pathology in the skin and muscle were epidermis separated from dermis, presence of fungal granuloma, vacuums, hemorrhage and necrosis. Loss of primary and secondary gill lamellae, hypertrophy and primary gill lamellae separated, necrosis and hemorrhage were found in the gill. Large vacuums, necrosis and hemorrhage were observed in liver and kidney. Among the affected fish organs skin and muscle, gills were more affected than the internal organs like liver and kidney. Overall, clinical and histological observations of fishes were found to be more affected in December and January. Whereas, in the months of mid February to April, the pathological condition of fish gradually healed up to normal except few vacuums and hemorrhage. Under histopathological observations, fishes of Kailla beel were more affected than the fishes of surma river. In clinical and histopathological observation open water fishes were more susceptible due to EUS.
\end{abstract}

Keywords: seasonal variation; small endangered species; clinical and histopathological observations; water quality parameters

\section{Introduction}

Bangladesh is very rich in inland freshwater resources. The inland water bodies include ponds, rivers, canals, reservoirs, lakes, Oxbow lakes, floodplains and natural depressions. The closed inland water resources are estimated 7.74 hectare of which 3.71 million hectare ponds, 0.055 million hectare oxbow lakes, 2.75 million hectare shrimp farm, 1.22 million hectare seasonal water bodies; 27.11 million hectare floodplains (DoF, 2013). These water bodies are good and ideal habitat for small indigenous fish (SIS) as well as many 
commercially important indigenous small fishes of Bangladesh such as catfish, cyprinids, perches, ell and snake headed etc. This species of fish always remain available for daily consumption of all classes of people especially low-income groups, due to their low price, food taste and good flavor and high nutritional quality. The small indigenous species (SIS) of Bangladesh are generally considered to be those fishes which grow to a length of about $25 \mathrm{~cm}$ or inches (Felts et al., 1996; Hossain and Afroze, 1991). SIS has high nutritional value in terms of protein, vitamin, and minerals and these micronutrients are not commonly available in other foods (Thilsted et. al., 1997). These groups of fish contain large amount of calcium and also iron and zinc (Tripathi, 1997). Moreover this small indigenous fish species are maintaining a stable and static condition of our aquatic food chain thus the biodiversity of our open water ecology have in smooth form. But natural populations of this small fish is rapidly decreasing due to over exploitation, lack of scientific management, draining out of beels, natural disaster (draught and siltation) and poor environmental conditions. Because the water quality of beels, baors, rivers and canals are decreasing day by day. As a result, fish species that breed and reared in natural waters are reducing quickly. Thus fishes of open water bodies are facing continuous stress, which leads to infection and disease. Health condition and disease has become a major problem in fish production both in culture system and wild condition in Bangladesh (Rahman and Chowdhury 1996). Common diseases of open water fishes of Bangladesh are tail and fin rot, bacterial gill rot, dropsy, various types of fungal disease, protozoan disease, parasitic disease, nutritional disease, tumors (Chowdhury, 1993). Although the existing fishes are habituated in floodplain but snakehead, catfish etc., are recorded as rare species from flood plains and beels due to the outbreak of various diseases (Hossain and Mazid, 1995). With the outbreak of epizootic ulcerative syndrome (EUS) in 1988, Channa spp., Puntius spp., Anabas spp. and other indigenous species of fish are seriously affected (Barua et al., 1989). The water quality parameters such as temperature, dissolved oxygen, $\mathrm{pH}$, total alkalinity, total hardness and ammonia could be associated with outbreaks of disease (Subasinghe, 1995). It indicated the possible relationship between the occurrence of disease and the environmental parameters. Histopathological technique is one of the most important procedures for disease diagnosis in fish. It has been successfully used throughout the world. It was thus necessary to investigate health condition of fish through some suitable techniques. Considering the above facts the present study has been undertaken with the following objectives are to investigate water quality parameters of Kailla beel and Surma river in relation to different months and also observe the health status of selected fish species from the two different areas with the seasonal variation.

\section{Materials and Methods}

In the present investigation two areas were selected; they were Kailla beel of Mymensingh region and Surma river of Sylhet region.The study was conducted for a period of eight months from September 2014 to April 2015 to find out the water quality parameters and health status of a small indigenous species (Baila, , Gutum and Tara baim). Water samples were collected from the Kailla beel and Surma river once in a month between 08.00 to 08.30 am and water quality parameters test on spot. Water quality parameters like temperature, $\mathrm{pH}$, dissolved oxygen, ammonia, total hardness, alkalinity and nitrite were measured by using respected test kits. Fish samples from both region was collected from nearby local fisherman. A total of 15 live fishes (5 fishes from each species) were collected during each sampling from each area. The sampled fishes were clinically examined by naked eye and magnifying glass to record any external signs, injury and other abnormalities. Organs like skin and muscle, gill, liver and kidney were collected with the help of a sharp scalpel and forceps and fixed in $10 \%$ neutral buffered formalin for histopathological study. After 8 hours of fixation, the samples were trimmed in order to obtain a standard size of $1 \mathrm{~cm}^{3}$ (maximum) and placed in automatic tissue processor for dehydration, clearing and infiltration. The samples were then embedded, sectioned ( $5 \mu \mathrm{m}$ thickness) and stained with Haematoxylin and Eosin. Then the sections were mounted with canada balsam and covered by cover slips and examined under a compound microscope. Photomicrograph of the stained sections was obtained by using a photomicroscope. Record of structural variations and pathologies were done from the slides and photomicrographs (Ahmed et al. 2009).

\section{Results}

\subsection{Water quality parameters}

Water quality of the Kailla beel and Surma river was studied from September 2014 to April 2015. Data regarding water temperature, $\mathrm{pH}$, dissolved oxygen (DO), and ammonia analyzed and presented in Table 1. 
Table 1. Monthly variations of water quality parameters of the kailla beel and Surma river.

\begin{tabular}{|c|c|c|c|c|c|c|c|c|c|}
\hline Parameters & $\begin{array}{l}\text { Water } \\
\text { body }\end{array}$ & Sep & Oct & Nov & Dec & Jan & Feb & Mar & Apr \\
\hline \multirow[b]{2}{*}{$\begin{array}{l}\text { Temperature } \\
\left({ }^{0} \mathrm{C}\right)\end{array}$} & Kailla beel & $31 \pm 1.27$ & $29 \pm 1.77$ & $26 \pm 1.89$ & $19 \pm 2.12$ & $17 \pm 2.54$ & $25 \pm 1.44$ & $28 \pm 1.26$ & $31 \pm 1.52$ \\
\hline & \begin{tabular}{|l|} 
Surma \\
river
\end{tabular} & $32 \pm 1.33$ & $30 \pm 1.54$ & $27 \pm 1.76$ & $21 \pm 3.25$ & $19 \pm 2.88$ & $27 \pm 1.33$ & $28 \pm 1.22$ & $33 \pm 1.01$ \\
\hline \multirow[b]{2}{*}{$\mathrm{pH}$} & Kailla beel & $6.9 \pm 0.25$ & $7.0 \pm 0.54$ & $6.8 \pm 0.75$ & $6.6 \pm 0.24$ & $6.8 \pm 0.33$ & $7.0 \pm 0.14$ & $7.1 \pm 0.43$ & $7.0 \pm 0.32$ \\
\hline & $\begin{array}{l}\text { Surma } \\
\text { river }\end{array}$ & $7.1 \pm 0.12$ & $6.9 \pm 0.11$ & $6.8 \pm .0 .23$ & $6.7 \pm 0.55$ & $6.7 \pm 0.57$ & $6.9 \pm 0.37$ & $7.0 \pm 0.26$ & $7.3 \pm 0.10$ \\
\hline \multirow[b]{2}{*}{$\begin{array}{l}\text { Dissolved } \\
\text { oxygen }(\mathrm{mg} / \mathrm{l})\end{array}$} & Kailla beel & $4.5 \pm 1.20$ & $4.0 \pm 1.03$ & $3.5 \pm 1.25$ & $3.0 \pm 1.75$ & $3.5 \pm 1.88$ & $4.0 \pm 1.01$ & $4.0 \pm 0.45$ & $4.5 \pm 0.67$ \\
\hline & \begin{tabular}{|l|} 
Surma \\
river
\end{tabular} & $4.5 \pm 1.11$ & $4.5 \pm 1.20$ & $4.0 \pm 1.03$ & $3.5 \pm 1.75$ & $3.0 \pm 1.83$ & $4.0 \pm 1.22$ & $4.5 \pm 0.24$ & $5.0 \pm 0.35$ \\
\hline \multirow[b]{2}{*}{$\begin{array}{l}\text { Ammonia } \\
(\mathrm{mg} / \mathrm{l})\end{array}$} & Kailla beel & $0.0 \pm 0.12$ & $0.0 \pm 0.01$ & $0.1 \pm 0.03$ & $0.3 \pm 0.05$ & $0.3 \pm 0.08$ & $0.1 \pm 0.04$ & $0.2 \pm 0.01$ & $0.0 \pm 0.01$ \\
\hline & \begin{tabular}{|l|} 
Surma \\
river
\end{tabular} & $0.0 \pm 0.01$ & $0.1 \pm 0.02$ & $0.1 \pm 0.04$ & $0.2 \pm 0.06$ & $0.3 \pm 0.09$ & $0.1 \pm 0.05$ & $0.0 \pm 0.02$ & $0.0 \pm 0.00$ \\
\hline
\end{tabular}

\subsection{Clinical observations}

Clinical symptoms of investigated species in different months of the Kailla beel and Surma river were studied and recorded (Table 2).

\subsubsection{Fish in Kailla beel}

During the month of September and October it was observed that, all the three species were almost normal and healthy in appearance. In G. giuris rough skin was observed in November, scale loss at some places in, hemorrhage in gill, Fin loss and scale loss from ventral region in December and January(Fig. 2). However, in December rough skin was observed in L. guntea and M. aculeatus. Rough skin, ectoparasitic infestation in gill, and deep ulcer of ventral region were recorded in L. guntea in December and January (Fig. 4). Same appearance was observed in M. aculeatus. in December (Fig. 6). In M. aculeatus fin loss and discoloration of gill filament were recorded in November, mild dermal lesion were observed in L. guntea at the same period.

\subsubsection{Fish in Surma river}

Healthy appearance and almost normal condition were observed during September, October and mid november in all the three species. During December and January rough skin was observed in G. giuris same appearance were observed in in L. guntea and M. aculeatus Weak body in last November, hemorrhage in dorsal and dorsoventral region during December and January were observed in P. ticto. Discolouration of gill filament during November, mild dermal lesion in December and January were recorded in L. guntea. In M. aculeatus severe necrotic lesion in head region was observed in December and loss of caudal fin in January.
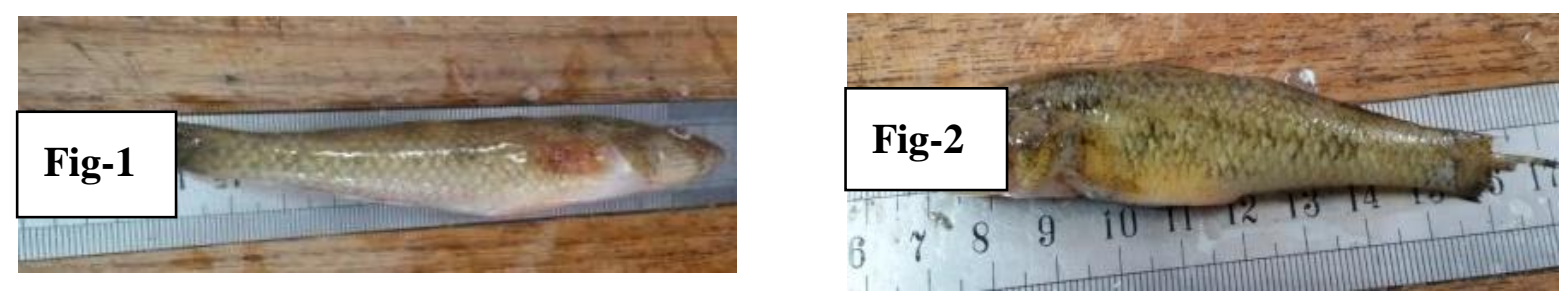

Figure1. G. giuris obtain from surma river in the month of September-october. Almost normal appearance.

Figure 2. G. giuris obtain from surma river in the month of January. Redness of eyes, hemorrhage in gill, total caudal fin loss and scale loss from dorsal region were seen. 

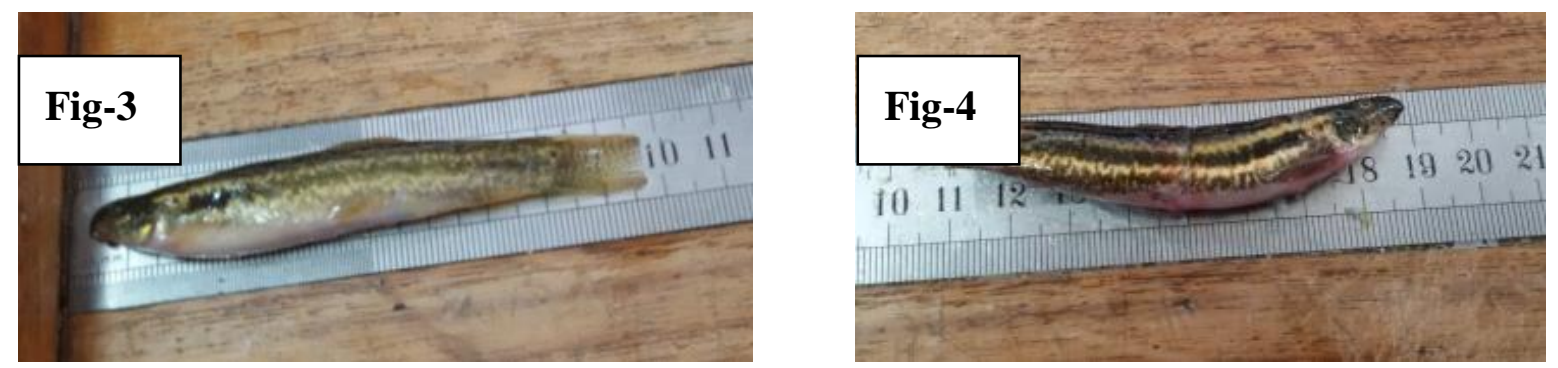

Figure 3. L.guntea obtain from Kailla beel in the month of September-october. Almost healthy appearance.

Figure 4. L. guntea obtain from Kailla beel in the month of December. hemorrhage in gill, Fin and total tail loss and Red spot and mass lesion in ventral region were seen.
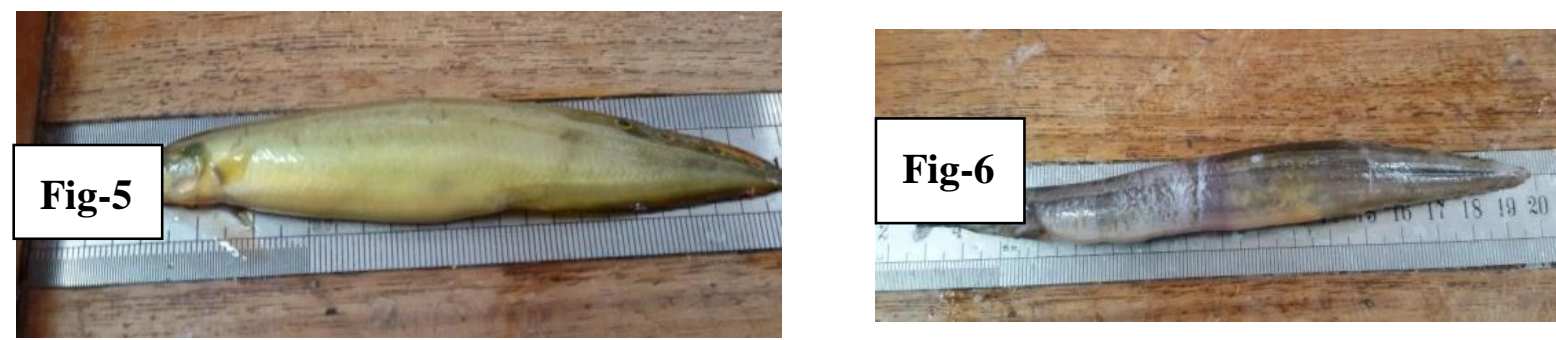

Figure 5. M. aculeatus obtain from Kailla beel in the month of March- April. Almost healthy appearance.

Figure 6. M. aculeatus obtain from Kailla beel in the month of January. Gill rot, loss of caudal fin and whitish lesion to deep ulcer and derrmal lesion in lateral region were seen.

Table 2. Clinical observation of investigated fish of the two beels in different months.

\begin{tabular}{|l|l|l|l|l|l|l|l|l|}
\hline Month & September & October & November & December & January & February & March & April \\
\hline $\begin{array}{l}\text { Kailla } \\
\text { beel }\end{array}$ & $\begin{array}{l}\text { Healthy } \\
\text { appearance }\end{array}$ & $\begin{array}{l}\text { Weak } \\
\text { body }\end{array}$ & $\begin{array}{l}\text { Fin } \\
\text { erosion, } \\
\text { mild } \\
\text { affected }\end{array}$ & $\begin{array}{l}\text { Whitish } \\
\text { deep ulcer, } \\
\text { weak body, } \\
\text { Lesion, FL. }\end{array}$ & $\begin{array}{l}\text { Large } \\
\text { ulcer, } \\
\text { weak } \\
\text { body,DB } \\
\text { RP, } \\
\text { RS. }\end{array}$ & WB & HA & HA \\
\hline $\begin{array}{l}\text { Surma } \\
\text { river }\end{array}$ & AN & AN & AN & $\begin{array}{l}\text { Numerous } \\
\text { 'R', 'WB', }\end{array}$ & $\begin{array}{l}\text { 'RS', } \\
\text { weak } \\
\text { body,EP } \\
\text { G }\end{array}$ & AN & AN & AN \\
\hline
\end{tabular}

$\mathrm{AN}=\mathrm{Almost}$ normal, $\mathrm{WB}=$ Weak body, $\mathrm{R}_{\mathrm{S}}=$ Red spot, $\mathrm{HA}=$ Healthy appearance. $\mathrm{RS}=$ Rough skin, $\mathrm{DB}=\mathrm{Deformetis}$ body, $\mathrm{EPG}=$ Ectoparasitic infestation in gill, $\mathrm{FL}=$ Fin loss.

\subsection{Histopathological Ovservation}

\subsubsection{Fishes of Kailla beel}

In September and october epidermis were normally arranged in all three fishes. However in December and January, a monogenean trematode was present in dermis of G. giuris (Fig. 9), splitted dermis, vaccum, necrosis, haemorrhage and protozoan cyst were observed in G. giuris, at that time same changes were found in L. guntea and M. aculeatus fishes in kailla beel. Marked hypertrophy was observed in gill lamellae. gill lamellae were splitted in some places of $L$. guntea, both the gill lamellae were ruptured with blood cells of L. guntea. At this time monogenetic trematode, protozoan cyst, haemoerrage were present in the gill of L. guntea and $M$. 
aculeatus during December and January. In mid October to November, secondary gill lamellae were swollen and primary gill lamellae were almost normal in all the three species. During this period in M. aculeatus, both the gill lamellae were hypertrophied and missing in some portion having monogenetic trematode. In December and January protozoan cyst, clubbing were present in secondary gill lamellae and heavy fungal granoluma and fungal hyphae were apparent in the skin and muscle of M. aculeatus. In the month of last February to April affected fishes were gradually healed with the changes of environment.

\subsubsection{Fishes of Surma river}

In case of G. giuris during the month September to November muscle more or less normal. In However, in December and January, dermis splitted, necrotic muscles were scattered in empty space and dense melanocytes were observed in dermis. In M. aculeatus epidermis partly lost and separated from dermis, dermis irregularly arranged and dense melanocytes, fungal granuloma were seen in December and January in Surma river. In case of G. giuris, in September to November all fishes more or less infection free and glossy appearance. In December and January, both the gill lamellae were hypertrophied, and many monogenetic trematode, protozoan cyst, talengiectasis were present in secondary gill lamellae, hemorrhage in both gill lamellae and secondary gill lamellae were missing in some places.

\section{Discussion}

Several research works had been conducted in Bangladesh on disease investigation of small indigenous fish with clinical and histopathological methods as disease diagnosis tools. In the present study, small indigenous fishes like are Baila (Glossogobius giuris), Gutum (Lepidocephalichthys guntea) and Tara baim (Macrognathus aculeatus) was considered to monitor health and disease in the kailla beel from Mymensingh and Surma river from Sylhet region of Bangladesh. The results of this study are discussed below and compared with the results of other works in the relevant field.

Water quality parameters are important considerations of fish health management. In the present study, the highest water temperature $31{ }^{\circ} \mathrm{C}$ in Kailla beels and $32{ }^{\circ} \mathrm{C}$ in Surma river was recorded in September (2014). On the other hand, the lowest value of temperature was recorded $17{ }^{\circ} \mathrm{C}$ in kailla beel and $22{ }^{\circ} \mathrm{C}$ in Surma river in January. Mondal (2012) recorded water temperature were ranged from 17 to $31^{\circ} \mathrm{C}$ in BAU fish farm. According to Akter et al. (2009) there was a decreased value of temperature during winter season in Kailla beel of Mymensingh. In the present experiment, the $\mathrm{pH}$ values were ranged from 6.6 to 7.1 in Kailla beel and 6.7 to 7.3 in Surma river. Mondal (2012) recorded that $\mathrm{pH}$ values were ranged from 7.0 to 7.7 in BAU fish farm and Swopon fish farm throughout the experimental period. Most natural water has $\mathrm{pH}$ values of 6.5 to 9 (Alim, 2005). According to Swingle (1967) $\mathrm{pH}$ value of 6.5 to 9 is suitable for fish culture. In the present experiment, the values of dissolved oxygen were ranged from 3.0 to $4.5 \mathrm{mg} / \mathrm{l}$ in Kailla beel and 5.0 to $3.0 \mathrm{mg} / \mathrm{l}$ in Surma river. Ahmed et al (2009) reported that dissolved oxygen ranged from 5.5 to 3.0 in four beels of Mymensingh. Hossain (2000) and Kohinoor (2000) recorded dissolved oxygen values of fish ponds ranging from 3.8 to 6.9 $\mathrm{mg} / \mathrm{l}$ and 2.04 to $7.5 \mathrm{mg} / \mathrm{l}$ respectively at Mymensingh region. In the present study, the values of ammonia were very much nearer that ranged from 0.0 to $0.3 \mathrm{mg} / \mathrm{l}$ in both the water bodies. Wahab et al. (1995) reported that ammonia content of 0.19 to $0.28 \mathrm{mg} / \mathrm{l}$ in their experimental areas. Akter et al. (2009) observed increased level of ammonia during winter period.

Clinically, G. giuris, L. guntea and M. aculaetus had almost normal except some fin erosions were recorded in November from Kailla beel. In January, large deep whitish ulcer reached up to deep ulcers, deformetis body, Ectoparasitic infestation in gill and Fin loss was observed from both water bodies. From research findings of Haque et al. (1999) it was observed that, large deep and whitish ulcer in the lateral and region, part of fins, scales and muscle were clinical sings of EUS affected fishes. Parveen (2001) observed that, three small indigenous fishes like P. ticto, $N$. nandus and C. punctatus from four beels of Mymensingh district, and observed that fishes were severely affected during the months of December and January. Ahmed et al.(2012) reported that the Tilapia was more affected from December and January and different clinical symptoms like rough skin, scale loss, red spots and dermal lesions were noticed. Ahmed et al. (2007) also observed that scale loss, ill body and rough skin, minor ulcer and small red spots in December and January. From the result of the present experiment it was observed that severities of clinical signs were increased in December and January in both region. In present study, selected species was more affected followed by Kailla beel than Surma river. 

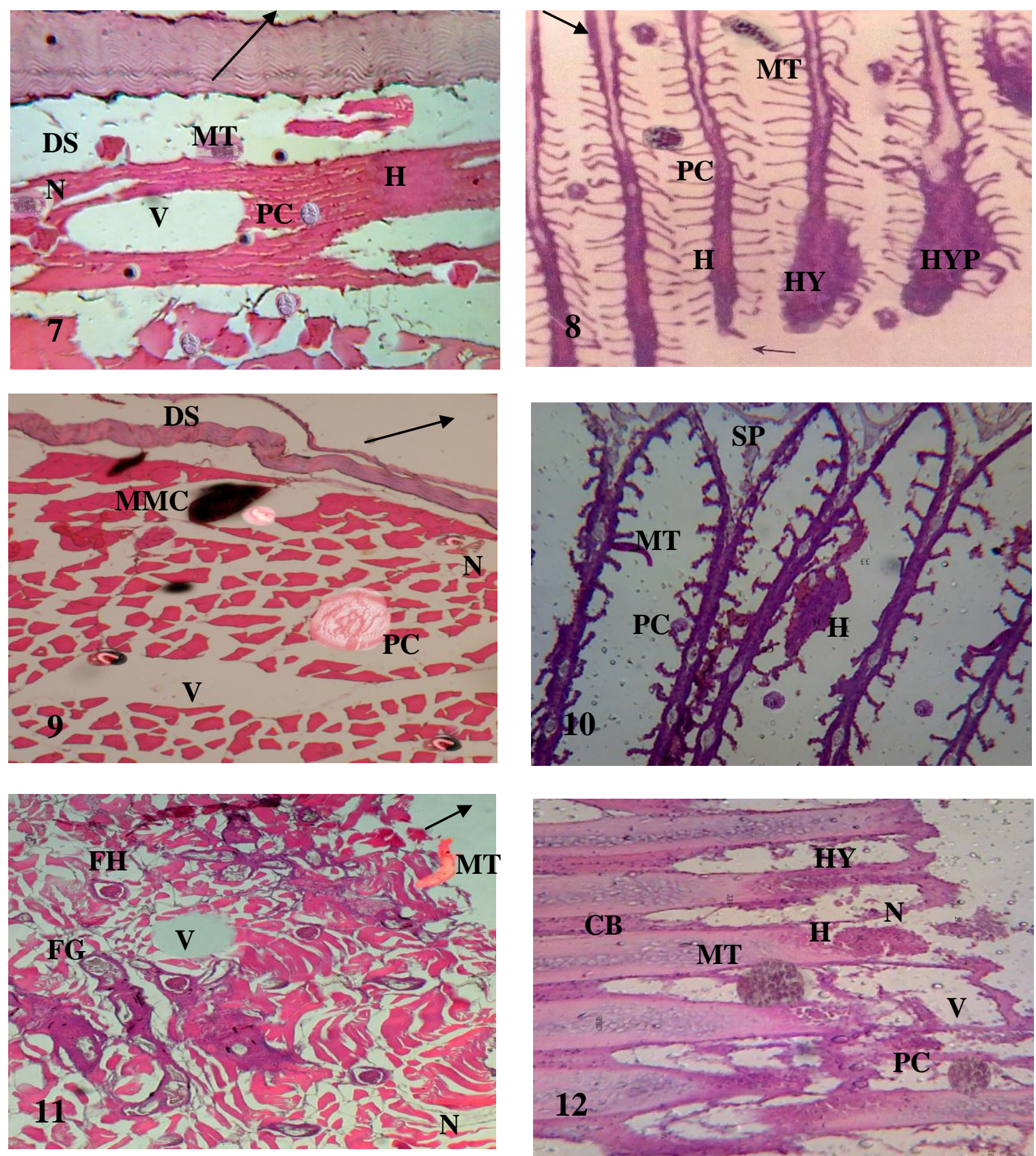

Figure 7. Cross section of affected of skin and muscle of $G$. giuris in January from surma river splitted dermis, monogenean trematode, vaccum, haemorrhage, necrosis and protogoan cyst (H\&E x 130).

Figure 8. Section severely affected of gill of $G$. giuris in January from surma river having monogenean trematode, haemorrhage, protozoan cyst, hypertrophy and hyperplasia (H\&E x130).

Figure 9. Photomicrograph of affected skin and muscle of $L$. guntea in December from Kailla beel dermis spilled, malenomacrophage centre, vaccum, necrosis and protogoan cyst (H\&E x130).

Figure 10. Cross section of severely affected of gill of $L$. guntea in December from kailla beel having monogenean trematode, haemorrhage, protogoan cyst, gill lamellae were splitted (H\&E x 130).

Figure 11. Photomicrograph of affected skin and muscle of M. aculaetus in December from Kailla beel fungal hypae, fungal granoluma, vaccum, necrosis, and monogenean trematode (H\&E x 130).

Figure 12. Cross section of severely affected of gill of $M$. aculaetus in December from kailla beel having monogenean trematode, haemorrhage, protogoan cyst, gill lamellae were splitted, clubbing, vaccum, hypertrophy (H\&E x 130). 
Histopathologically, it was observed in present study that all organs of fishes likes gill, skin and muscle, liver and kidney was almost normal in October, mild affected in November and severely affected in December and January and infected organs were healed up to almost normal structure in March and April from both water bodies. In January, primary gill lamellae were separated; vaccum, Haemorrhage, protozoan cyst, monogenean trematode, clubbing, necrotic and hypertrophied in fishes of kailla beel. Whereas, fish organs of Surma river hemorrhage, necrosis, hypertrophied and hyperplasic in December. Konika (2011) observed less pathological changes such as hypertrophy, clubbing and few lamellar missing in Cirrhinus cirrhosus during November. According to Ahmed et al. (2012) O. niloticus gill had hypertrophy, hyperplasia, clubbing, hemorrhage in primary gill lamellae and secondary gill lamellae were lost during December and January. According to Ahmed et al. (2009) gills were healed up to almost normal structure in February and March. Muscle had fungal granuloma, fungal hyphe, Monogenean trematode, vaccums and necrosis in muscle of M. aculaetus from Kailla beel in December. However, in Surma river, muscle had splitted dermis, protozoan cyst, vacuums, necrosis and hemorrhage in January. Ahmed et al. (2010) also observed that epidermis and dermis were partly lost, necrosis, hemorrhage, fungal hyphae were seen in A.testudineus during the months of December and January. Hossain $e t$ al. (2009) reported that severe necrosis of hepatocytes, pyknosis, vacuoles, fat droplets and hemorrhage were observed in small indigenous species during December and January. Ahmed et al. (2012) observed that in February and March, organs pathology was recovered to almost normal structure except vacuums. In the present study, internal organs such as liver and kidney were less affected than external organs like skin, muscles and gill.

The water quality parameters were in suitable range throughout the study period except temperature, and ammonia which were reduced in December and January. In December and January when water temperature was $17^{\circ} \mathrm{C}$ to $19^{\circ} \mathrm{C}$, diseases like EUS, red spot, parasitic infestation and numerous abnormalities occurred with marked pathological changes in various organs. Fish samples were collected at monthly intervals. Under clinical observations, any injury, infection and other abnormal conditions of fish body were recorded. In present study, sample fish was almost normal during the month of September and October. The fish had numerous clinical sings seen in lateral and ventral regions during Decembe rand January from Surma river. Whereas, large deep whitish ulcers reached up to deep ulcers, red spot, rough skin, fin lose were found during December and January in fish of kailla beel. In this experiment it is observed that the fishes of surma river comparatively less affected than the fishes of kailla beel. During histopathological study, normal structure was found in September from both water bodies. Mild pathological changes were seen in the Kailla beel during November. However, pathological changes were increased in the fish in December and January. Under Pathological observation, fish was affected by epizootic ulcerative syndrome (EUS), red spot, tail and fins rots, gill rot, parasitic infestation and nutritional deformities etc. The gill and skin and muscle in fish was more affected then internal organs likes liver and kidney due to those diseases.

\section{Conflict of interest}

None to declare.

\section{References}

Ahmed F, 2010. Histopathological studies of carps, catfishes and a perch experimentally infected with Aeromonas Hydrophila bacteria, MS Thesis, Department of Aquaculture Bangladesh Agricultural University, Mymensingh.

Ahmed GU, M Dhar, MNA Khan and D Choi, 2007. Investigation of diseases of Thai Koi, Anabas testadineus (Bloch) from Farming Conditions in winter. Journal of Life Sciences, 17: 1309-1314.

Ahmed GU, MM Hossain and MM Hassan, 2009. Seasonal variation of disease and pathology of a perch, Nandus nandus from Oxbow-lake fisheries of Bangladesh. Ecofriendly Agriculture Journal, 2:761-767.

Ahmed GU, T Khatun, MB Hossain and M Samsuddin, 2012. Health condition of a farmed tilapia (oreochromis niloticus) in earthen ponds, Northern Bangladesh. Bangladesh Journal of Fisheries, 12:287293.

Akter MN, GU Ahmed and MS Hossain, 2009. Seasonal variation of gill pathology of a climbing perch in lake fisheries of Bangladesh. International Journal of Animal and Fisheries Sciences, 2: 208-213.

Alim MA, 2005. Developing a polyculture technique for farmer's consumption and cash crop, $\mathrm{PhD}$ Dissertation, Department of Fisheries Management, Bangladesh Agricultural University, Mymensingh. 
Barua G, ANH Banu and MH Khan, 1989-91. An investigation into the prevalence of fish disease in Bangladesh during 1988-1989. Bangladesh J. Aquacult., 11:75 -79.

Chowdhury MBR, 1993. Research priorities for microbial fish disease and its control in Bangladesh. In: Proceeding of the Workshop on Research Priorities of Bangladesh for fish health, disease prevention and pathology. May 17, edited by Alam Tollervey. pp. 8-11.

Felts RA, F Rajts and M Akhteruzzaman, 1996. Small indigenous fish species culture in Bangladesh (Technical Brief), IF ADEP sub-project- 2. Development of Inland Fisheries. pp.41.

Haque MA, MS Hossain, GU Ahmed and Z Tazri, 2009. Clinical and pathological investigation disease in some small indigenous species (SIS) from fish markets of Mymensingh. International Bioresearch, 7:1-6.

Hossain MA and S Afroze, 1991. Small fish as a resource in rural Bangladesh. Fishbyte, 9:16 -18.

Hossain MY, 2000. Effects of 150 prosperous organic and inorganic fertilizers on water quality parameters and biological production, MS Thesis, Department of Fisheries Management, Bangladesh Agricultural University, Mymensingh.

Hossian MS and MA Mazid, 1995. A manual on development of floodplain fisheries. Fisheries Research Institute, Mymensingh. p. 2 (In Bengali).

Khatun T, 2011. Study of health condition of farmed tilapia (Oreochromis niloticus), from two upazilas of Mtmensingh region, MS Thesis, Department of Aquaculture, Bangladesh Agricultural University, Mymensingh.

Kohinoor AHM, 2000. Development of culture technology of three small indigenous fish mola (Amblypharyngodon mola), punti (Puntinus sophere) and chela (Chela cachius) with notes on some aspects of their biology. APhD dissertation, Department of Fisheries Management, Bangladesh Agricultural University, Mynensingh.

Konica MK, 2011. Investigation on culture and health status of mrigal Cirrhinus cirrhosus from the farming system of Mymensingh region, MS Thesis, Department of Aquaculture, Bangladesh Agricultural University, Mymensingh.

Mondal A, 2012. Investigation on the health status of some exotic fishes from farming condition of Mymensingh area, MS thesis, Bangladesh Agricultural University, Mymensingh.

Parveen R, 2001. Disease investigation of three small indigenous fishes from beel of Mymensingh, MS Thesis, Department of Aquaculture, Bangladesh Agricultural University, Mymensingh.

Rahman AKA, 1989. Fresh water fishes of Bangladesh, Zoological Society of Bangladesh, Dhaka. pp. 364.

Rahman MM and MBR Chowdhury, 1996. Isolation of bacterial pathogen causing an ulcer disease in farmed carp fishes of Mymensingh. Bangladesh Journal of Fisheries, 19:103 -110.

Subasinghe RP, 1995. Note on Fish Disease Diagnosis and Health Management Training Workshop held from 22nd to 25th February, 1995. FRI, Mymensingh. pp. 3 -21.

Swingle HS, 1967. Standardization of chemical analysis for waters and pond muds. FAO Fish Reproduction, 4: 397-421.

Thilsted SH, N Roos and N Hassan, 1997. The role of small indigenous fish species in food and nutrition security in Bangladesh, NAGA News letter, July December pp.13.

Tripathi SD, 1997. The role of fisheries and Aquaculture in improving the food and nutrition security in Bangladesh. Paper presented at the Training workshop in food nutrition security in Bangladesh. Organized by BRR! And ENRECA project, 12 March 1997, Bangladesh.

Wahab MA, ZF Ahmed, MA Islam and SM Rahmatullah, 1995. Effect of introduction of common carp, Cyprinus carpio (L), on the pond ecology and growth of fish polyculture. Journal Aquaculture Research, 26: 619-628. 